\title{
Study on the Ideological and Political Education Mode Innovation in Colleges and Universities in the New Era
}

\author{
Wang Qingbao \\ Baicheng Normal University, Baicheng 137000, China \\ wqb1105@163.com
}

Keywords: Ideological and Political Education in Colleges and Universities, Socialist Thought with Chinese Characteristics, Education Mode Innovation, New Era

\begin{abstract}
On October 18, 2017, the 19th National Congress of the Communist Party of China opened in Beijing. The report of the 19th National Congress put forward a new historical orientation for the development of socialism with Chinese characteristics has entered a new era. In the new era, with the economic transformation and upgrading, political anti-corruption, institutional reform, ideological and political work in colleges and universities in the new era has also new demands and new tasks. The new era calls for a new educational model to help college students understand and learn better the Xi Jinping spirit and essence of socialism with Chinese characteristics in new era, and to cultivate the "new era" in accordance with the requirements of the times. This paper analyzes the necessity and importance of the mode innovation of ideological and political education in colleges and universities in the new era, and probes into the advantages and opportunities of the mode innovation of ideological and political education in colleges and universities in the new era, and on the basis of this, focus on the summary and analysis of the innovative methods of ideological and political work education mode in colleges and universities in the new era.
\end{abstract}

\section{Introduction}

In order to realize the new goal of national construction in the new era, education in the new era should have new achievements. As the beginning year of carrying out the ideas of the 19th national congress of the Communist Party of China in 2018, the report of the 19th national congress of the Party calls for the full implementation of the Party educational policy and carry out the fundamental task of building up people by virtue. Under the new standards and requirements of the new era, colleges and universities must actively promote the teaching mode innovation of ideological and political work to adapt to the requirements of the new era, and push the ideological and political work of colleges and universities into a new stage in the new era to provide strong talent support for the progress of the new era and the national rejuvenation.

\section{The Necessity and Importance of the Ideological and Political Education Mode Innovation in Colleges and Universities in the New Era}

\subsection{New Era, New Ideas and New Requirements Calling for a New Teaching Model.}

The French philosopher Bergson famously said that new concepts must be created for new objects. At present, socialism with Chinese characteristics has entered a new era, Chinese economy has entered a crucial period of transformation and upgrading, new progress has been made in combating corruption and advocating clean government and institutional reform in China, and the main contradictions in Chinese society have also changed. Chinese diplomacy has also changed from "away diplomacy" to "home diplomacy." the party and state leaders, with President Xi Jinping as the center, have made new additions and new developments to the theory of socialism with Chinese characteristics in the face of changes at home and abroad, who have put forward new viewpoints and new opinions, and makes new contributions to the Sinicization of Marxism [1]. It is precisely because of the renewal of new theories, the youth education in the new era and university 
education that the new teaching mode is called upon to carry out the ideological education work to help young students to better understand Xi Jinping socialist ideology with Chinese characteristics in new era.

\subsection{Cultivating "the New Person of the Times" with the Ideal, the Ability and the Responsibility.}

Franklin, one of the three founding nations of the United States, once said, "the education of young people is the cornerstone of a nation." In order to cultivate the "new people of the times" with a sense of national honor and national responsibility, who have the courage to bear the responsibility of national rejuvenation and lead the national construction of the new era, colleges and universities must strengthen the ideological and political work and promote the educational mode innovation of ideological and political work, and let young students have a deeper understanding of the connotation of socialist theory with Chinese characteristics, better train students ideological and moral qualities, set up correct three views, and arm the minds of young students with Marxism through the development of teaching activities. To guide the practice of young students, so that they, being the future of the nation and the country, can better understand the world and transform the world, become an ideal, competent "new people of the times" , to help the new era of national construction and national rejuvenation[2].

\section{The Advantages and Opportunities of the Ideological and Political Education Mode Innovation in Colleges and Universities in the New Era}

\subsection{Progress in Science and Technology.}

The 21 century is an era of scientific and technological innovation. The position of science and technology is becoming more and more important in the competition of big countries. The progress of network technology also provides an opportunity for the development of network teaching of ideological and political work education. The network effectively draws closer the distance between teachers or related scholars and students, which can carry out online video teaching activities, and can also watch the lectures of well-known scholars on video education networks such as MOOCS, NetEase open class, etc. Students in the forum can also exchange their feelings and ideas with each other and make common progress. At the same time, students can also offer advice on the innovation of the ideological and political work education model in colleges and universities in the new era on the corresponding websites. In a word, the progress of network science and technology provides a new opportunity for the innovation of ideological and political education mode in colleges and universities in the new era.

\subsection{The High Attention Payed by the Department Concerned.}

In the new era, the Party and the state attach great importance to the development of ideological education, and the relevant departments such as the Ministry of Education actively respond to the new educational concepts in the new era and promote the innovation of the educational mode of supervising the ideological and political work in colleges and universities, and actively organize the exchange among colleges and universities, through the convening of ideological and political work education model of the exchange conference, draw on the relevant experts and teachers of each university unique excellent educational model, and promote to all colleges and universities throughout the country, in order to facilitate the innovation of the ideological and political work education model nationwide, in addition to this, the relevant parts also regularly carry out videoconferencing deployment tasks, transmit ideas, organize inspection and supervision groups, and enter universities and colleges to carry out a visit to the political, ideological and political work in colleges and universities[3]. It is also due to the attention, arrangement of the relevant departments of the Party and the state that the ideological and political education mode innovation in colleges and universities in the new era is guaranteed. 


\section{Innovative Methods of Ideological and Political Work Education Mode in Colleges and Universities in the New Era}

\subsection{Strengthening the Construction of Ideological and Political Education Team in Colleges and Universities with New Ideas.}

As a guide to students learning, teachers play an important role in students understanding and mastering the new contents of ideology and politics in the new era. A good teacher can help the whole class to better understand the theory of socialism with Chinese characteristics and better understand the process of Sinicization of Marxism, but if the ideological and political education camp is mixed with people who are ideologically wrong, it will seriously hinder the development of ideological and political education, and have a bad impact to establish a correct world outlook and values outlook and other ideological concepts for students on life on the school, and even worse, it will seriously harm the development of ideological and political work education in colleges and universities. Therefore, we must strengthen the construction of the teaching staff. We should cultivate a group of teachers who safeguard the interests of the Party and the country, safeguard socialism with Chinese characteristics, and devote themselves to the cultivation of "new people of the times" in order to better serve the ideological and political work of colleges and universities in the new era[4].

\subsection{The Innovation of Ideological and Political Education Content in Colleges and Universities in the New Era under the Guidance of New Theory.}

Xi Jinping socialism of new era with Chinese characteristics was put forward by the 19th national congress, which was put forward by party and state leaders with Xi Jinping as the center according to Chinese current economic, political and cultural conditions. On the basis of Deng Xiaoping theory, three represent thought and scientific development view, the scientific cognition and new theory obtained from the practice since the 18th national congress of the Communist Party of China (CPC) have been added. At the same time, the theoretical content of ideological and political education in colleges and universities must also be expanded, the original textbooks and related monographs must be recompiled, and the existing theories and new theories should be combined to eliminate the theories that do not conform to the contents of the new era. In addition, it is necessary to increase the new theory of the new era, to rearrange the proportion of each content in the teaching material and the teaching content, to put the overall layout of the five in one in $\mathrm{Xi}$ Jinping new era socialist thought with Chinese characteristics, and the four overall development strategies, to comprehensively promote the modernization of national defense and the armed forces, as well as the foreign affairs of big countries with Chinese characteristics, to increase the contents of teaching, and to reformulate curriculum standards that meet the requirements of the new era. Under the guidance of the new theory, the content of ideological and political education in colleges and universities in the new era should be innovated.

\subsection{Making Full Use of the Progress of Science and Technology in the New Era.}

The progress of network technology also provides an opportunity for the development of network teaching in ideological and political work education, and provides technical support for the teaching mode innovation. In the development of ideological and political work in colleges and universities, we should make full use of the progress of science and technology in the new era, and maximize the benefits of network science and technology to ideological and political education. On the one hand, in the classroom, teachers can broadcast documentaries about the struggle of the Communist Party or the development of Marxism in China through multimedia technologies such as video and audio, so that students can understand the perseverance of the Communists more clearly. For the sake of the great spirit of the people, we can also have a deeper understanding of why China has chosen Marxism and the theoretical support that Marxism provides for the development and construction of China. At the same time, we can broadcast moving revolutionary stories, which also helps to cultivate the patriotic spirit and the sense of hardship among college students. On the other hand, students can be organized to watch experts and scholars from 
well-known colleges and universities teach courses such as the principles of Marxism, Mao Zedong thought and an introduction to the theoretical system of socialism with Chinese characteristics in the admiration class and NetEase cloud open class to help students have a deeper understanding and awareness of these theories. Moreover, colleges and universities can narrow the distance between students and teachers by introducing advanced teaching techniques such as flipping classes [5]. In short, the development of science and technology is conducive to the development of new teaching of ideological and political courses in colleges and universities, each university should give full play to the role of network science and technology in the mode innovation of ideological and political work education.

\subsection{Promoting the Ideological and Political Education Mode Innovation in Colleges and Universities in a New Way in the New Era.}

In the face of the new requirements and new standards of ideological and political education in colleges and universities in the new era, colleges and universities should adopt a more diversified teaching method, and it is necessary not only to carry out classroom teaching, but also to organize various activities to promote college students understanding of the principles of Marxism, Mao Zedong thought and the theory of socialism with Chinese characteristics. For example, we can carry out drama and musical performances so that students can participate in the performance, better understand the struggle of generations of socialists, raise the ideological and political awareness of college students, or we can conduct related speech competitions. The competition between fiction and poetry makes them realize that only Marxism can save China and give full play to the role of cultural education. The development of activities to go to the countryside is also a major innovation in the way of ideological and political education in colleges and universities. Schools and teachers encourage students to carry out activities in the countryside, to enter the countryside, to experience the new changes in the new era, and to use scientific theories to carry out investigations and visits. The visit not only promoted the students rapid growth, cultivated the team spirit of students, strengthened the student perseverance, but also increased their understanding of why China chose Marxism. Cultivate their sense of responsibility and commitment to the great rejuvenation of the Chinese nation, and cultivate a "new era" with ideals, skills, and responsibilities. In addition, the development of the "three down-country" activities has provided assistance for the construction of a new rural area in China. In the process of college students' contact with the investigation and research villages, they have brought advanced management experience to the rural areas and also enhanced the student' understanding of the rural areas [6]. In a word, the development of practical activities such as "three down-country" is an innovation of the ideological and political work education mode in colleges and universities in the new era, which is helpful to the ideological and political work in colleges and universities.

\subsection{The Ideological and Political Work in Colleges and Universities in the New Era Must be Student-Oriented and Teach Students in Accordance with Their Aptitude.}

In the new era, the ideological and political education in colleges and universities must take the students as the main body and the training of excellent socialist successors as the goal. In the ideological education classroom of colleges and universities, teachers should pay attention to the main position of the students and prepare lessons for the students. Lectures are for students, and all work of teachers is for students to better understand the principles of Marxism and the connotation of socialism with Chinese characteristics, to enhance the ideological awareness of students, and to carry out teaching models and methods around students. The individuality of the teaching content should try to inspire the students to study the new theory of the new era with the most vivid language, and help the students to understand the teaching content of the ideological and political education in colleges and universities more deeply with the most accurate language, the whole teaching process cannot be separated from the students and should build efficient classrooms around students. Teaching students in accordance with their aptitude is also an important way to improve the quality of ideological and political education in colleges and universities in the new era. Each student is an independent individual, with a unique gift different from others. There are 
differences in the memory, learning methods, the original knowledge reserve, thinking ability, classroom activity and character among the students. Therefore, in the process of ideological and political teaching, teachers and experts in related fields must choose different teaching methods according to each student personality and teach them according to their aptitude to improve the efficiency of ideological and political education, to establish an efficient classroom, and to help the ideological and political education learning of each student.

\section{Conclusion}

Zheng Guanying once said in "Western Studies": "the school, the land where talent is created, the foundation for governing the world." The party and state leaders, with Xi Jinping as the center, attach great importance to educational activities and train reliable successors of socialism. Under the new requirements of the new era, colleges and universities will also respond to the call of relevant departments. Under the guidance of $\mathrm{Xi}$ Jinping socialism thought with Chinese characteristics in the new era, we should seize the opportunity of the development of network science and technology, actively carry out the mode innovation of ideological and political work education in colleges and universities, and strengthen the construction of the contingent of ideological and political education. We should add new theories in time, carry out related activities to raise the ideological consciousness of contemporary college students, and cultivate them into "new people of the times" who have the courage to undertake the important task of national rejuvenation and progress. At the same time, in the face of the new requirements for ideological and political workers put forward by new theories and new ideas, and the new challenges that follow, the leaders and participants of ideological and political work in colleges and universities must face the problems directly, never evade them, and solve them in a timely manner, and steadily promote the innovation of ideological and political work in colleges and universities in the new era.

\section{Acknowledgements}

In this paper, the research was sponsored by the Educational Science Project of Jilin province during“13th Five-Year Plan”in 2017 (No. GH180563).

\section{References}

[1] Xi Jinping stressed at the National Conference on ideological and political work in Colleges and Universities that ideological and political work should be run through the whole process of education and teaching to create a new situation for the development of higher education in China [N]. Peoples's daily, 2016-12-09(1).

[2] CHEN Zhanan. Some thoughts on promoting the construction of ideological and political theory course in colleges and universities [J]. Leading Journal of Ideological \& Theoretical Education, 2010, 16(28):101-103.

[3] CAI Jile. Speeding up the construction of great power of education with the idea of socialism with Chinese characteristics in the new era: a visit to the deputy to the Nineteenth National Congress, Secretary of the party group of the Ministry of Education and Minister of State Chen Baosheng [N]. Education of China, 2017-10-22(01).

[4] XI Jinping. Be a good teacher with the satisfaction of the party and the people: speech at the symposium with the teachers and students of Beijing Normal University [EB/OL]. 2014-09-09.

[5] YANG Zhicheng. A new realm of the development of the theoretical system of socialism pedagogy with Chinese characteristics: a study of Xi Jinping educational thought [J]. Journal of the Chinese Society of Education, 2017(5):1-8.

[6] ZHANG Chuan, WANG Lin. Chongqing three gorges college: do three great articles and strengthen the party building to promote teaching [N]. Chongqing Daily, 2017-10-20(34). 